Accepted version:

Daoud, R., Starkey, L., Eppel, E., Vo T.D., \& Sylvester, A. (2020). The

educational value of internet use in the home for school children: A systematic

review of literature, Journal of Research on Technology in

Education, DOI: 10.1080/15391523.2020.1783402

\title{
The educational value of Internet use in the home for school children: A systematic review of literature.
}

Rana Daoud, Louise Starkey, Elizabeth Eppel, Tho Doan Vo and Allan Sylvester

\begin{abstract}
This article presents a systematic review of literature that explores the educational value of the Internet in the home for school aged children. Research published between 2008 and 2018 was examined and 67 items were analyzed. A range of positive, negative and neutral correlations or outcomes of home Internet use were identified across the three functions of education; academic achievement and skills, developing the individual and socialization. Overall, there were significantly more positive correlations or outcomes reported. We conclude that there is educational value in home Internet use and the value is influenced by the nature of online activities.
\end{abstract}

Keywords: Internet, Literature Reviews, Education, Home Internet,

\section{Introduction}

Schools and homes in many countries started connecting to the Internet in the 1990s at a time when a connection was relatively expensive, slow and online educational resources were limited as was the functionality for teaching and learning. Over time the Internet has become more accessible to homes and schools. Different governments and initiatives worked to provide Home Internet Access to school aged students like UK's Home Access Programme which ran from 2008-2010 (SQW, 2011) and the 2009-2019 ConnectED initiative in the US (Whitehouse, 2015). In New Zealand, the government has provided Ultrafast or Rural Broadband access to $98 \%$ of schools and aims to have fiber broadband accessible to $87 \%$ of New Zealanders in their homes by 2022 (UFBNZ, 2018). Since the 1990s, mobile devices have improved in functionality and affordability and the growth of digital tools for learning has broadened beyond sending and receiving email and accessing information from the Internet. The schooling sector is becoming connected to high speed Internet and has increasing access to learning management systems, online educational resources and communication tools that enable collaboration between students, and home and school.

Learning has never been confined within the boundaries of school buildings with children and young people continue to learn beyond the school environment through a range of contexts including online through the Internet. The nature of online learning is 
diverse and includes informal learning (Ferguson, Faulkner, Whitelock, \& Sheehy, 2015), independent study using curriculum materials, continuing activities started at school (Kerawalla et al., 2007) or through individualized or group homework activities set by teachers (Epstein \& Van Voorhis, 2001). Like the learning that occurs at school, learning at home increasingly makes use of the Internet. Children and young people use a range of digital devices connected to the Internet within the home including tablets, smartphones, gaming devices, Internet connected toys and voice activated devices (Brisson-Boivin, 2018). The closing of schools during the Covid-19 pandemic in 2020 emphasized the importance of home Internet access. With the growth of Internet access, it is timely to evaluate the educational value of the Internet in the home for school aged children.

The educational value of Internet access in the home is a substantive issue, particularly for policy makers considering questions of equity. If home Internet access has significant educational value for children and young people than those without access will be disadvantaged. Reviews of literature have explored children and young people's use of the Internet at home including the health effects such as Internet gaming disorder (Paulus, Ohmann, Von Gontard, \& Popow, 2018), cyberbullying (Kiriakidis \& Kavoura, 2010), and the effect of screen-time (Lissak, 2018). Other reviews have explored the development of digital skills (Buckingham, Banaji, Carr, Cranmer, \& Willett, 2005) or the effect of parenting styles on Internet use (Özgür, 2016). The educational value of the Internet at home has not yet been reviewed and it is timely to do so, to identify overall findings to inform future research agendas.

The definition of educational value in this article is framed within Biesta's three functions of education; qualification, socialization and subjectification (2009). Qualification is the knowledge, skills, dispositions and understanding to be able to do something, including different types of literacy, preparation for the world of work and to participate in society. The qualification function includes academic achievement measurements within the school setting. The socialization function prepares children to be members of society through citizenship education and ways of being and doing that are the norms of society. This includes explicit and implicit expectations around communication, relationships and interactions. Subjectification is derived from the humanist notion of individuality, it enables 'those being educated to become more autonomous and independent in their thinking and acting' (Biesta, 2009, p. 41). This conceptual framework recognizes educational value as including academic achievement, socialization and strengthening individuality.

This systematic review focuses on the substantive issue of the educational value of home Internet access for school aged children through the research question: What is the educational value of home Internet access? This is framed within Biesta's three functions of education: qualification, socialization and subjectification (2009).

\section{Method}

An exploratory, bounded systematic review was undertaken guided by the five criteria for systematic reviews identified by Hallinger (2013). These include; explicit research 
questions, a conceptual framework that guides the analysis and interpretation of studies, explicit search criteria and procedures, types of sources identified, and clarity of methods of data extraction.

Four stages were undertaken to systematically review the literature (Figure 1).

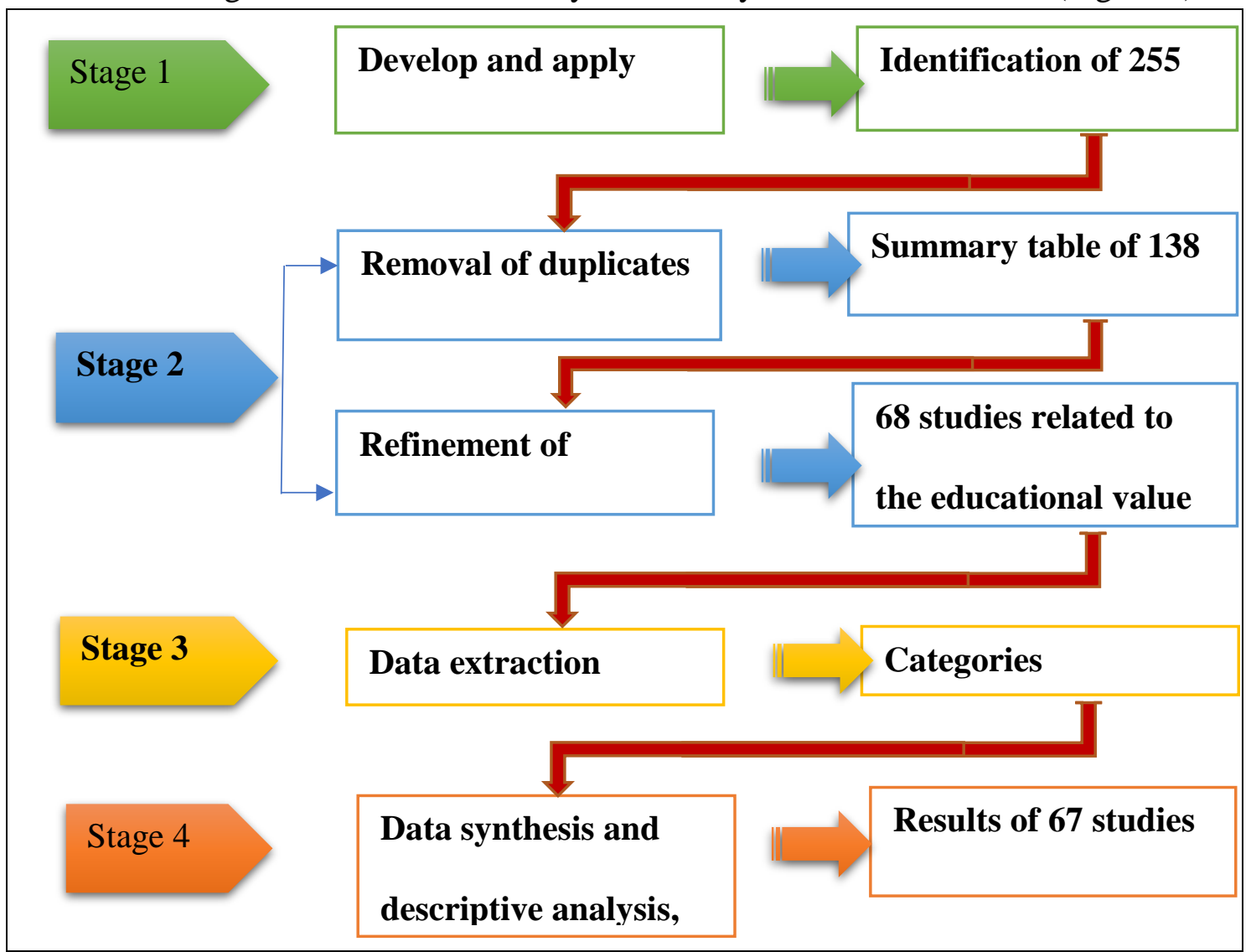

Figure 1 The stages of the literature review

The first stage of a systematic review is to develop a search strategy to locate relevant peer reviewed research articles (Kitchenham, 2004). Years were restricted to 2008 to 2018; this decision was made because Internet speed, the technology and the available educational applications have changed over time and earlier studies may be contextually different to the current day. The focus of articles reviewed was limited to school age children with early childhood, higher education, and articles with a sole focus on special needs education excluded.

Three broad sources of research articles were searched. The first data source was three journal aggregation databases: EBSCO education sources, Proquest (ERIC) and A+ education (Australasian specific). These databases combined include an extensive range of journals that publish in the area of digital technology and education. The data bases were searched using a Boolean string derived from the research questions that included the key terms "home" AND "Internet" AND (learn* OR achievement OR school OR education) in the abstract of published articles. The second source were searched using a mixture of keywords and manual searching of organizations or databases known to publish research or reports specifically in this topic area. This included theses, OECD library, and Pew Internet and American Life publications. In addition, New Zealand specific sources were explored including NZCER, Ministry of Education reports and the 
20/20 Communications Trust publications. This focus was taken as the researchers are based in New Zealand. The third data source was specific quality journals which publish in this area. This included Computers and Education, Computers and Human Behavior, Behavior and Information Technology, British Journal of Educational Technology, Technology, Pedagogy and Education, and Learning Media and Technology. These journals were manually searched through reading titles of all articles published since 2008. As a result of this process 255 potential articles, theses or reports were identified (Table 1).

Table 1. Number of articles identified at initial screening by source, Stage 1

\begin{tabular}{|l|l|l|}
\hline Source & Search type & $\begin{array}{l}\text { Number of } \\
\text { articles identified }\end{array}$ \\
\hline EBSCO- education source & Boolian & $91^{*}$ \\
\hline Proquest (ERIC) & Boolian & $81^{*}$ \\
\hline A+ Education & Boolian & $1^{*}$ \\
\hline Journals & Manual search & $44^{*}$ \\
\hline $\begin{array}{l}\text { Reports from organisations eg. } \\
\text { Pew Internet, OECD library }\end{array}$ & Key word/manual search & 22 \\
\hline New Zealand specific sources & Manual search & 7 \\
\hline Theses & Keyword/manual search & $9 *$ \\
\hline \multicolumn{1}{|c|}{$*$ peer reviewed } & &
\end{tabular}

The second stage began with the removal of duplicates and screening remaining articles beyond their abstract for the relevance to the goals of the review. Hallinger (2013) emphasizes the importance of quality assessment. In this review, we included qualitative, quantitative or mixed method studies with empirically supported findings that had been peer reviewed in journals and theses. We also included three reports that have not been peer reviewed but reported the outcomes of three initiatives that enabled students from low socioeconomic communities and developing countries to access Internet at home. (Beuermann, Cristia, Cruz-Aguayo, Cueto, \& Malamud, 2013; Jesson, Meredith, \& Rosedale, 2015; Starkey, Sylvester, \& McRae, 2017). Conceptual or theoretical studies, and articles that that did not report a robust methodology or were not clearly written were excluded. We included 138 studies that fitted broadly with the research aim to identify educational value of home Internet access.

A summary table was developed that included the context, the focus of the research and research questions, the methodology, and the results of each study. Five of the 138 articles were randomly selected and discussed by the research team to ensure inter-researcher consistency in decisions of inclusion, as recommended by Kitchenham (2004). Each member of the research team reviewed the five articles and considered other questions of inclusion or exclusion that emerged through the selection and data extraction process. As a result, the inclusion criteria were refined to ensure educational value was explicitly identified in the studies. In addition, articles which reported data gathered prior to 2005 were excluded due to contextual time difference. Among the 138 summarized studies, 68 met the refined inclusion criteria. 
The third stage was data extraction. This involved identifying and classifying the value of home Internet access in each of the reviewed articles, and the nature of that educational value. Prior to synthesis, we classified the 68 studies into three methodological categories each focused on a particular type of evidence:

(1) Correlation-focused Research: This category included studies examined the relationship between home Internet access and different educational aspects. These studies were all quantitative except for one which used mixed research methods. The correlation studies reported findings generated from questionnaires or surveys that explored the relationship between home Internet access and a range of educational aspects.

(2) Perspectives-focused Research: The studies in this category focused on exploring students', parents' and to a lesser extent teachers' views and opinions about the impact of home Internet access on students' education. These studies used questionnaires/surveys and/or interviews/focus group to explore peoples' perceptions.

(3) Investigation-focused Research: The previous categories investigated the relationships and the perceptions, while this category includes intervention studies that explored the impact of home Internet access. In these studies, a combination of methods like pre-post-tests, questionnaires, case studies, interviews, focus group, and logs were used to explore, measure, or evaluate the positive, negative, or no-impact of home Internet use on different aspects of education.

As this was an exploratory review that included qualitative, quantitative and mixed methods research of differing variables and foci a 'vote-counting' approach was undertaken. The educational value was considered positive when the study reported a positive correlation or a positive outcome such as improvement in students' performance or positive attitudes. The negative value was when the study reported a negative correlation or negative outcomes. Finally, when the study reported weak or no correlation was found or no change had occurred as a result of using Internet at home the educational value was considered neutral.

The fourth stage was data synthesis and descriptive analysis of the articles. Critical analysis and synthesis are intertwined to generate knowledge about the focus of a literature review (Torraco, 2016). The findings from the selected studies were synthesized and grouped into similar areas of educational achievement and factors that influenced educational achievement to develop conceptual classifications of constructs. This process was undertaken by two researchers, independently initially, to increase interrater consistency of judgements. The educational outcomes were coded and grouped to similar categories and the clustering of categories within the three functions of education. Additional revision was conducted and led to excluding one study which did not meet inclusion criteria and moving one study to another category. The total number of the selected articles was 67 studies classified into 34 correlation-focused studies, 13 perspectives-focused studies, and 20 investigation-focused studies. 
Table 2. A summary of the 67 reviewed studies.

\begin{tabular}{|c|c|c|c|c|c|c|c|c|c|c|c|c|c|c|c|c|c|c|c|c|c|c|}
\hline \multirow{3}{*}{$\#$} & \multirow{3}{*}{ Researcher \& year } & \multirow{3}{*}{$\begin{array}{c}\text { Research } \\
\text { focus \& } \\
\text { number** }\end{array}$} & \multirow{3}{*}{ Country } & \multirow{3}{*}{$\begin{array}{l}\text { Research } \\
\text { Type }\end{array}$} & \multirow{3}{*}{ Methods } & \multirow{3}{*}{ Age group } & \multicolumn{16}{|c|}{ Key Themes ${ }^{\star \star \star}$} \\
\hline & & & & & & & \multicolumn{7}{|c|}{ Qualification } & \multicolumn{7}{|c|}{ Subjectification } & \multicolumn{2}{|c|}{$\begin{array}{l}\text { Sociali- } \\
\text { sation }\end{array}$} \\
\hline & & & & & & & GA & $\mathrm{Li}$ & $\mathrm{Ma}$ & SS & $\mathrm{Sc}$ & DC & $\mathrm{AS}$ & $\mathrm{CD}$ & At & Mo & $\mathrm{Sf}$ & Ss & ED & AA & SD & DA \\
\hline 1 & $\begin{array}{l}\text { Acar Güvendir, } \\
(2017)\end{array}$ & CR1 & Turkey & $\begin{array}{l}\text { Journal } \\
\text { Article }\end{array}$ & Quantitative & 15 yrs. & & & 0 & & & & & & & & & & & & & \\
\hline 2 & $\begin{array}{l}\text { Acar, } \\
(2015)\end{array}$ & CR2 & Turkey & $\begin{array}{l}\text { Journal } \\
\text { Article }\end{array}$ & Quantitative & $15 \mathrm{yrs}$. & & - & & & & & & & & & & & & & & \\
\hline 3 & $\begin{array}{l}\text { Agić, et.al. } \\
(2016)\end{array}$ & CR3 & Bosnia & $\begin{array}{l}\text { Journal } \\
\text { Article }\end{array}$ & Quantitative & $\begin{array}{l}\text { High school } \\
\text { students }\end{array}$ & + & & & & & & & & & & & & & & & \\
\hline 4 & $\begin{array}{l}\text { Akyol, et.al } \\
(2010)\end{array}$ & CR4 & Turkey & $\begin{array}{l}\text { Journal } \\
\text { Article }\end{array}$ & Quantitative & 13 yrs. & & & & & - & & - & & & & & & & & & \\
\hline 5 & $\begin{array}{l}\text { Alshehri } \\
(2017)\end{array}$ & PR1 & $\begin{array}{l}\text { Saudi } \\
\text { Arabia }\end{array}$ & $\begin{array}{l}\text { Journal } \\
\text { Article }\end{array}$ & Mixed & $\begin{array}{c}\text { High school } \\
\text { students }\end{array}$ & + & & & & & & & & & + & & & & & & \\
\hline 6 & $\begin{array}{l}\text { Anastasiades, et.al. } \\
(2008)\end{array}$ & PR2 & $\begin{array}{c}\text { Greece \& } \\
\text { Cyprus }\end{array}$ & $\begin{array}{l}\text { Journal } \\
\text { Article }\end{array}$ & Quantitative & $11-12$ yrs. & & & & & & & & & & & & & & & + & \\
\hline 7 & $\begin{array}{l}\text { Araque, et.al. } \\
(2013)\end{array}$ & IR1 & USA & $\begin{array}{l}\text { Journal } \\
\text { Article }\end{array}$ & Mixed & $\begin{array}{l}\text { School aged } \\
\text { children }\end{array}$ & + & & & & & & & & & & & & & & & \\
\hline 8 & $\begin{array}{l}\text { Berkowitz, } \\
(2015)\end{array}$ & IR2 & USA & $\begin{array}{l}\text { Journal } \\
\text { Article }\end{array}$ & Quantitative & Grade 1 & & & + & & & & & & & & & & & & & \\
\hline 9 & $\begin{array}{l}\text { Beuermann, et.al. } \\
(2013)\end{array}$ & IR3 & Peru & Report & Quantitative & $\begin{array}{c}\text { Primary students } \\
\text { (5-11 yrs.) }\end{array}$ & & & & & & 0 & & 0 & & - & & & & & & \\
\hline 10 & $\begin{array}{l}\text { Cabiness, et.al. } \\
(2013) .\end{array}$ & IR4 & USA & $\begin{array}{l}\text { Journal } \\
\text { Article }\end{array}$ & Quantitative & Grade 7 & & & & + & & & + & & & & & & & & + & \\
\hline 11 & $\begin{array}{l}\text { Casey, } \\
(2012)\end{array}$ & CR5 & Ireland & $\begin{array}{l}\text { Journal } \\
\text { Article }\end{array}$ & Quantitative & 9 yrs. & & + & + & & & & & & & & & & & & & \\
\hline 12 & $\begin{array}{l}\text { Chen, et.al. } \\
(2018)\end{array}$ & CR6 & Singapore & $\begin{array}{l}\text { Journal } \\
\text { Article }\end{array}$ & Quantitative & $10-15$ yrs. & & + & & & & & & & & & & & & & & \\
\hline 13 & $\begin{array}{l}\text { Cheung, et.al. } \\
(2013)\end{array}$ & CR7 & $\begin{array}{c}\text { Hong Kong \& } \\
\text { South Korea }\end{array}$ & $\begin{array}{l}\text { Journal } \\
\text { Article }\end{array}$ & Quantitative & 15 yrs. & & + & & & & & & & & & & & & & & \\
\hline 14 & $\begin{array}{l}\text { Davies, } \\
(2011)\end{array}$ & IR5 & UK & $\begin{array}{l}\text { Journal } \\
\text { Article }\end{array}$ & Mixed & $8-17$ yrs. & & & & & & & & & & & & & & + & & \\
\hline 15 & $\begin{array}{l}\text { Di Blas \& Paolini, } \\
(2013)\end{array}$ & IR6 & Italy & $\begin{array}{l}\text { Journal } \\
\text { Article }\end{array}$ & Mixed & 5-18 yrs. & & + & & & & & & & & + & & & & & + & \\
\hline
\end{tabular}




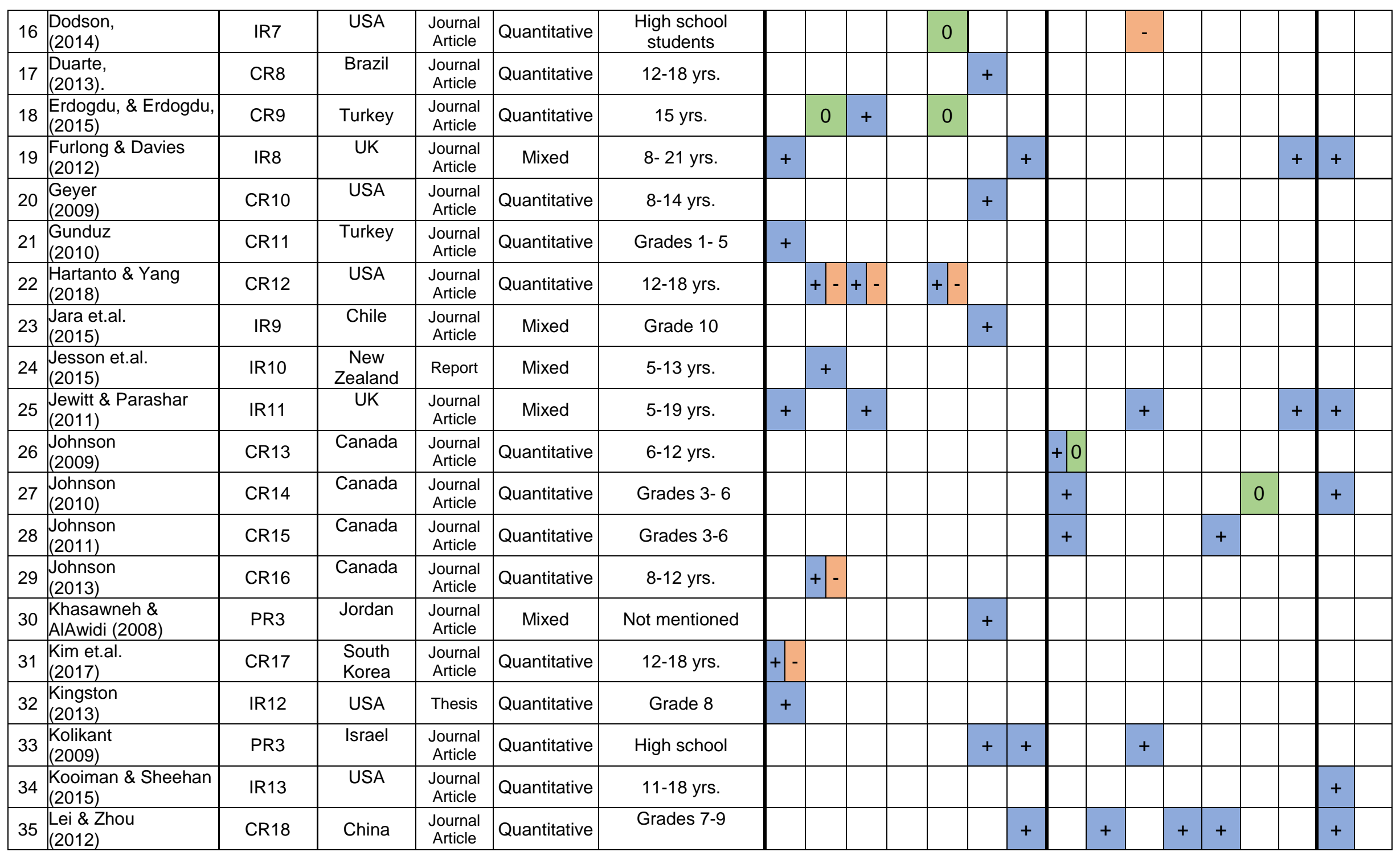




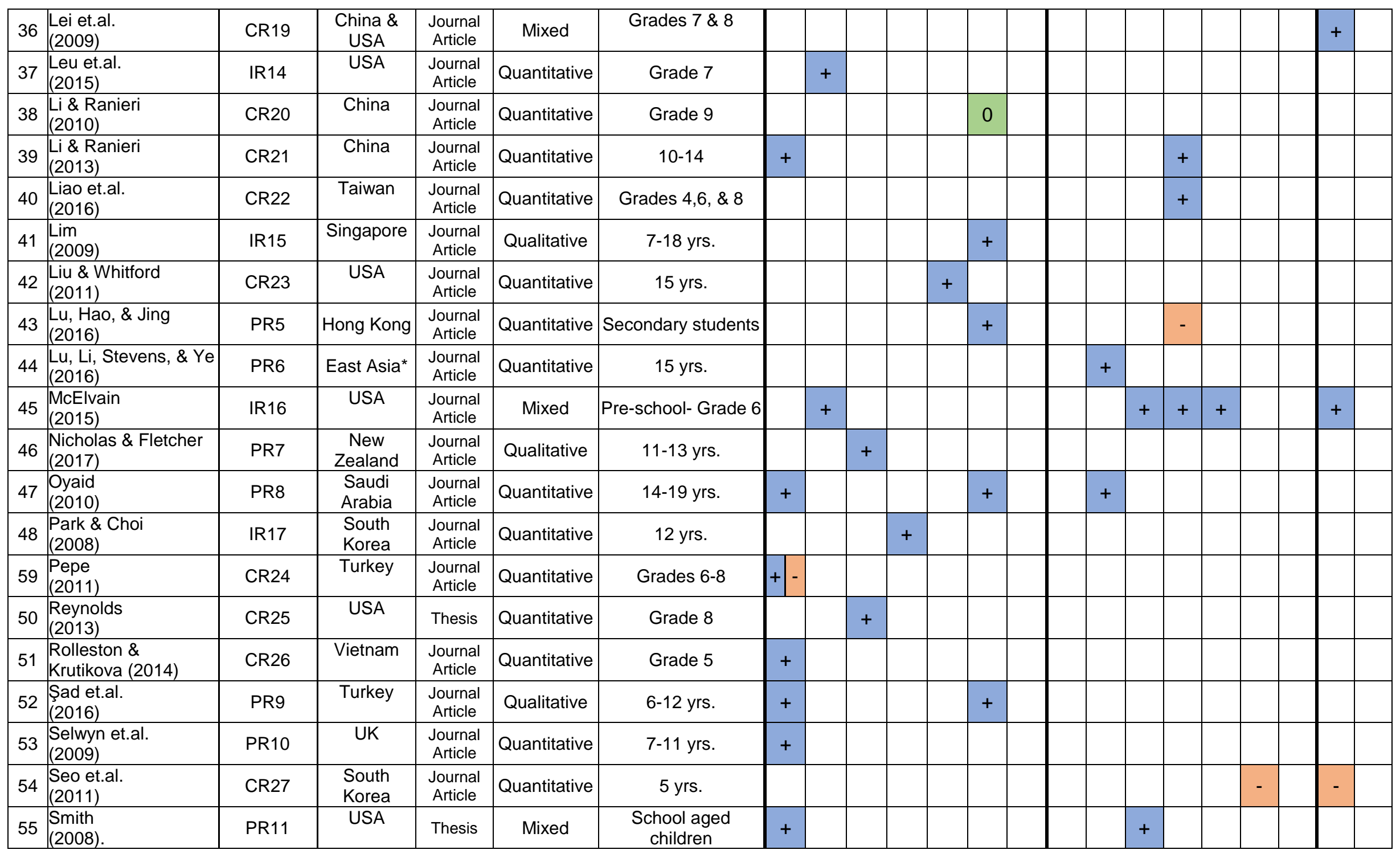




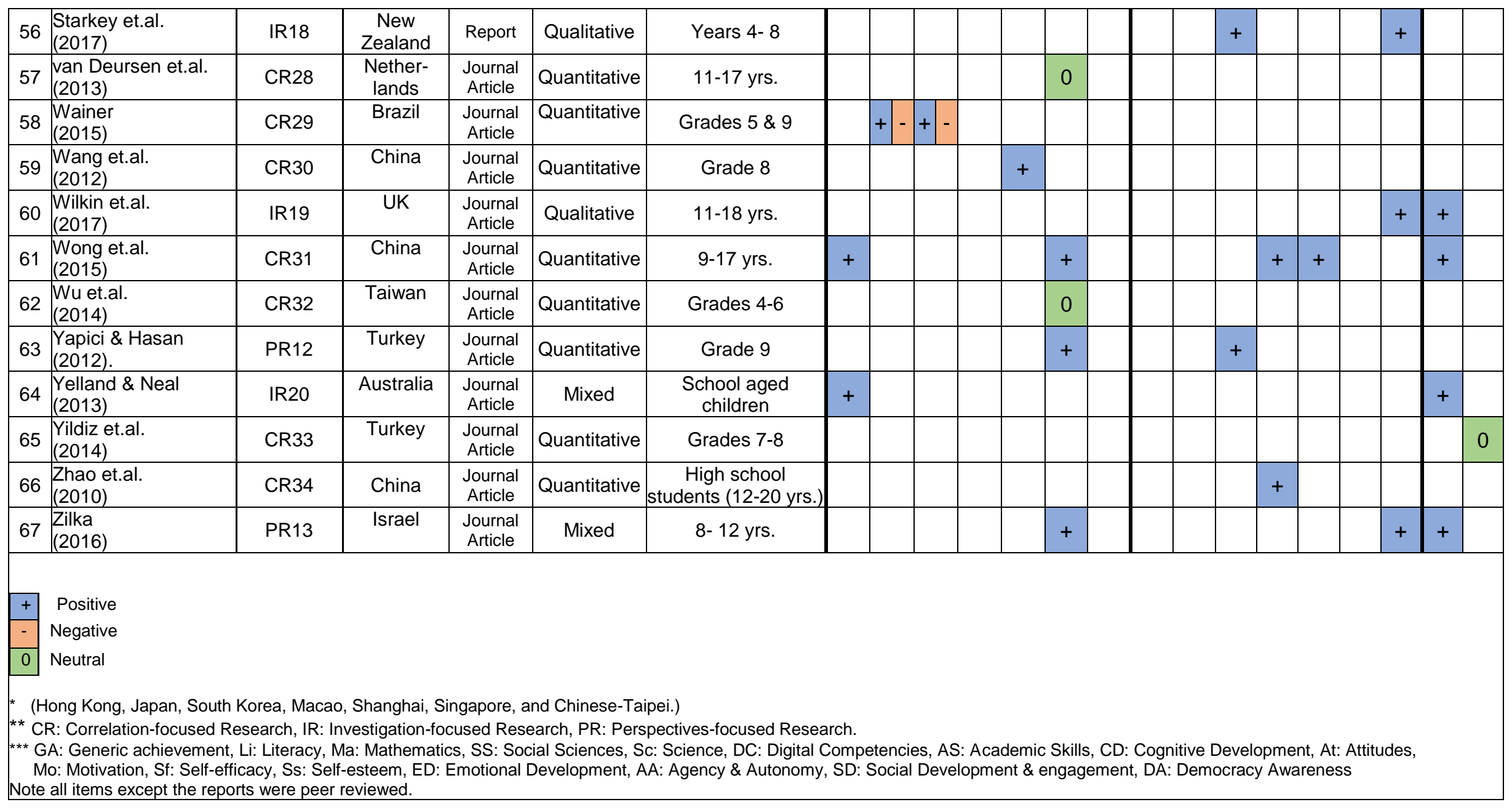




\section{Results and discussion}

\section{Attributes of the reviewed studies}

The studies that met the criteria included 61 journal articles, three reports and three doctoral dissertations. The majority of the studies were quantitative (48 studies) most of which were correlation-focused research. Mixed methods research included 14 studies, nine of which were from the investigation-focused category (9 studies out of 14). There were five qualitative studies that investigated the impact of home Internet access or explored the perceptions of the participants (Figure 2).

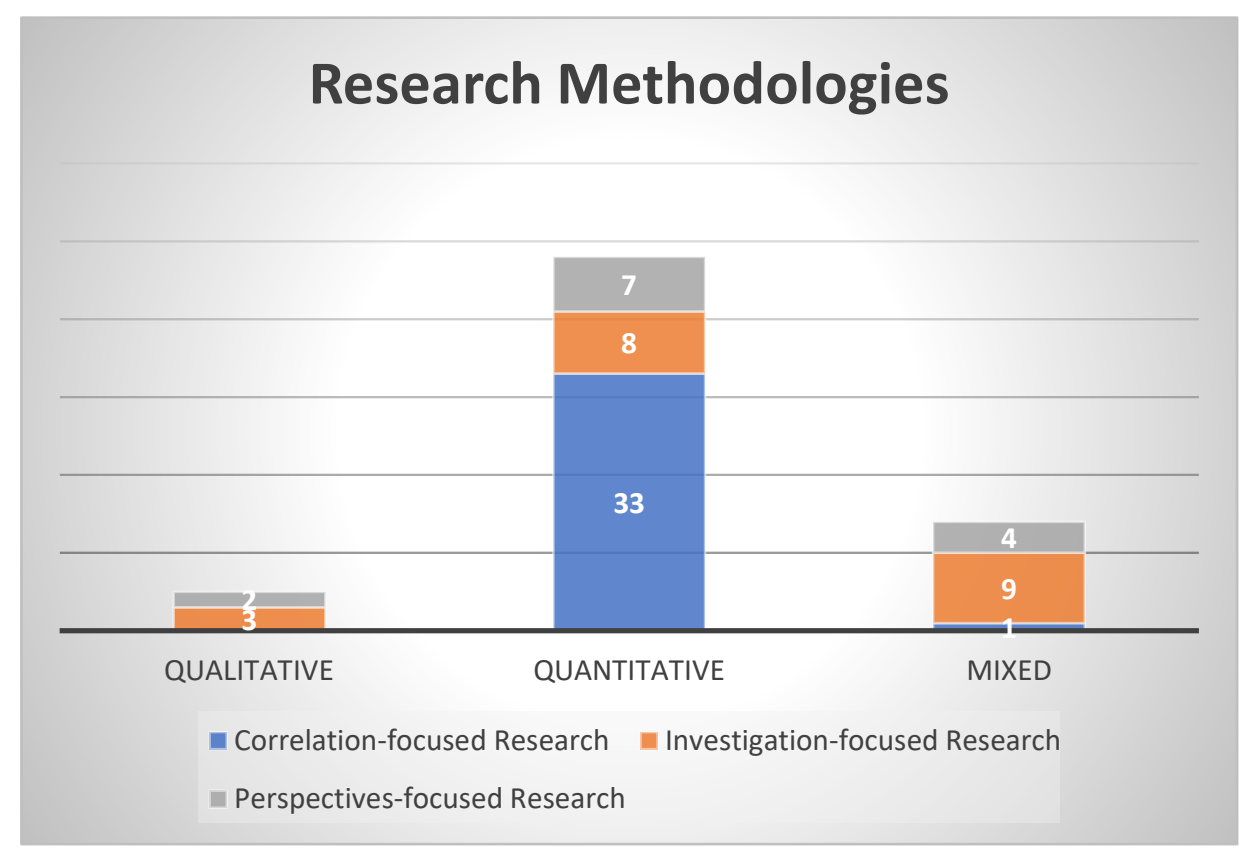

Figure 2. Research methodologies

The selected studies were undertaken in a range of countries (Figure 3). Some studies were conducted in more than one context (e.g., Lei, Zhou, \& Wang, 2009; Lu, Li, Stevens, \& Ye, 2016) others were conducted in the same context but addressed different educational values (Johnson, 2009, 2010, 2011, 2013). While, China, USA and Turkey were the most researched individual countries, there were no studies that met the inclusion criteria from Africa. 


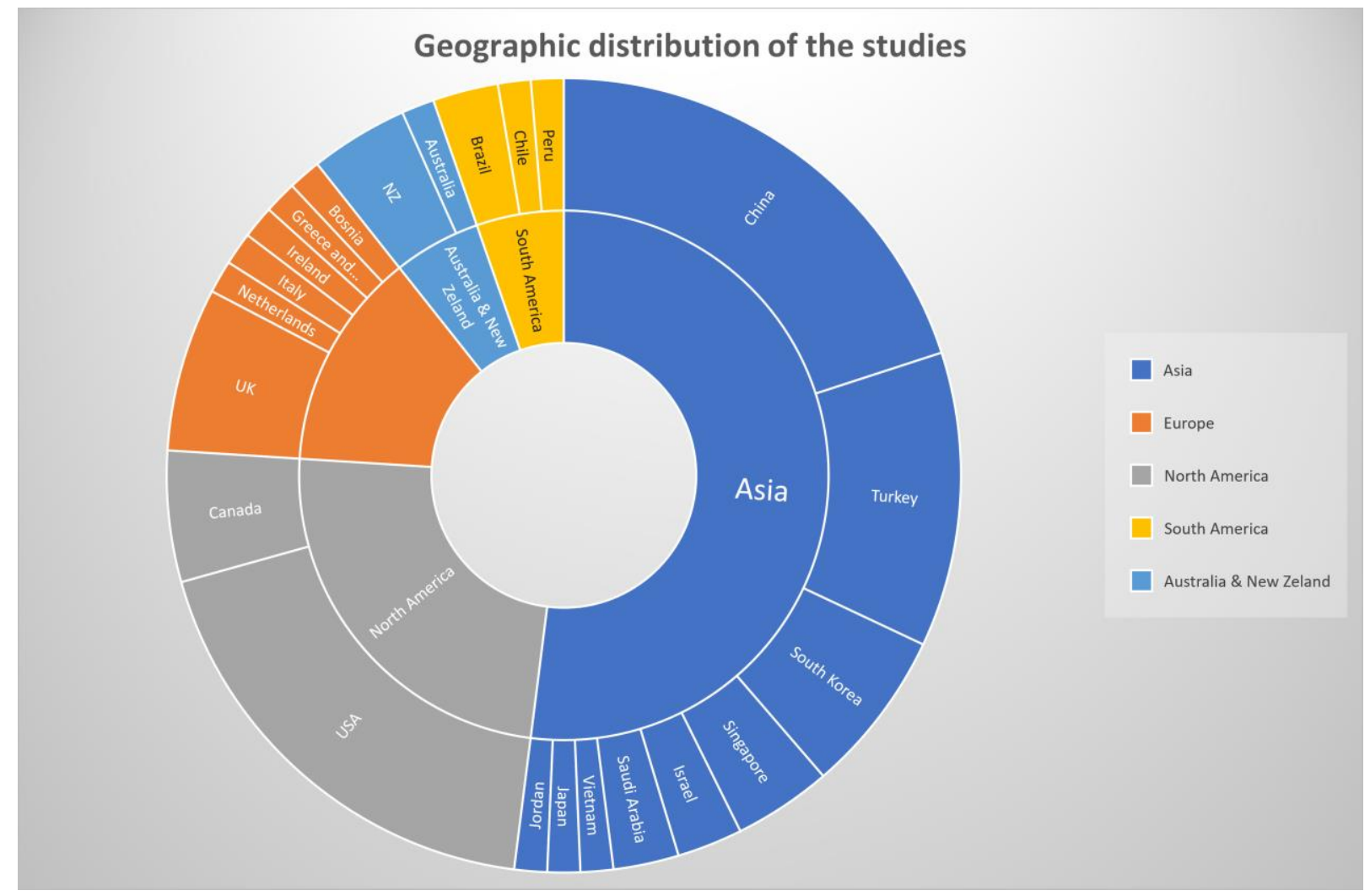

Figure 3. Geographic distribution of the studies

The educational value of home Internet access is grouped into the three functions of education identified by Biesta (2009) qualification, subjectification and socialization (Figure 4). The articles within the review identified aspects of educational value within these three functions and were grouped together when exploring similar types of educational value. 


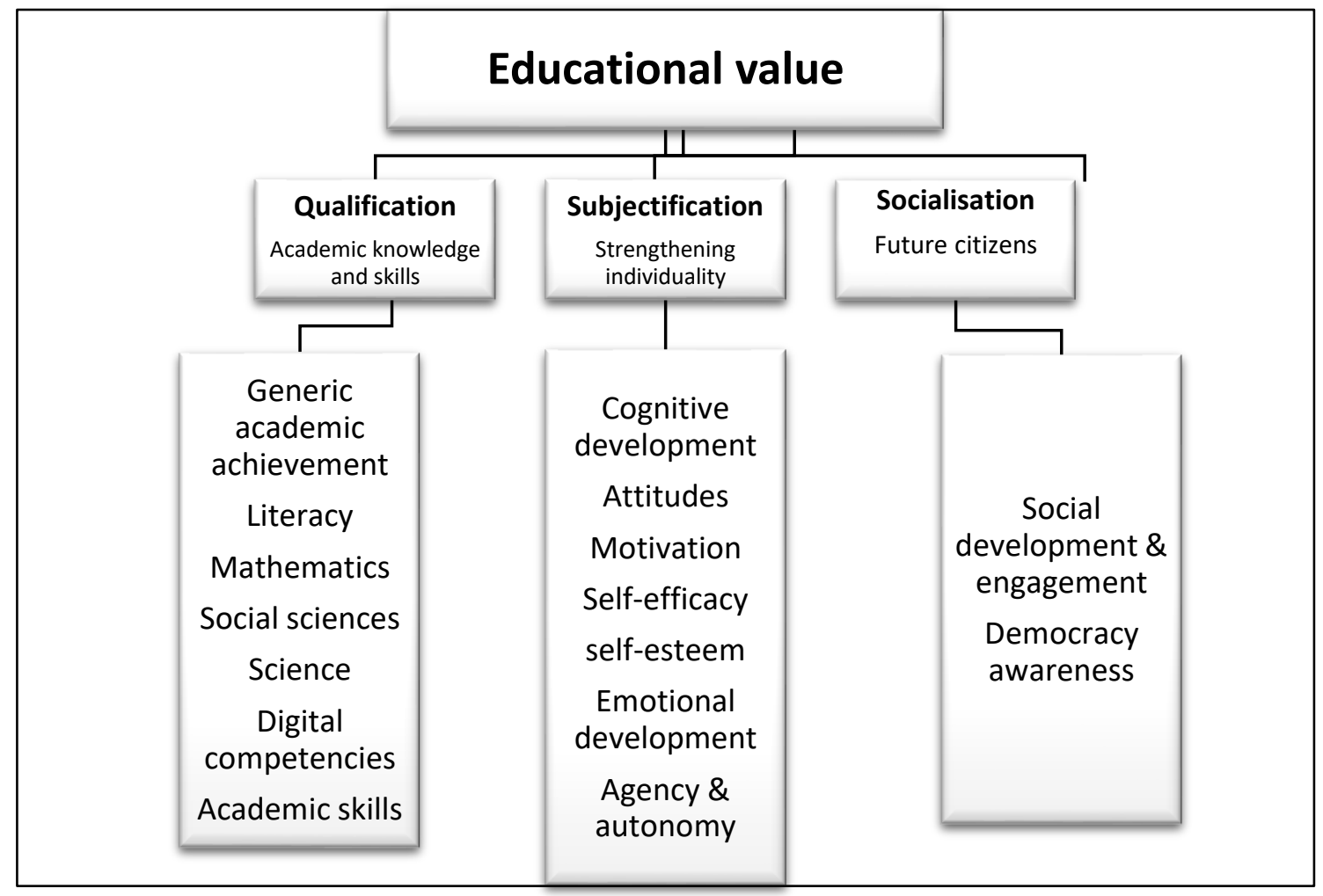

Figure 4. Educational value of home Internet use

[Table 2 about here]

\section{Qualification: Academic knowledge and skills}

Academic knowledge and skills were interpreted broadly in this review to include any school subject or skills associated with academic endeavors that had been associated with home Internet use in the research literature. In the process of analysis these were identified then grouped within categories including generic academic skills, literacy, mathematics, science, social science, digital competencies and academic skills. (Figure 5). Some of the studies examined outcomes in more than one category. 


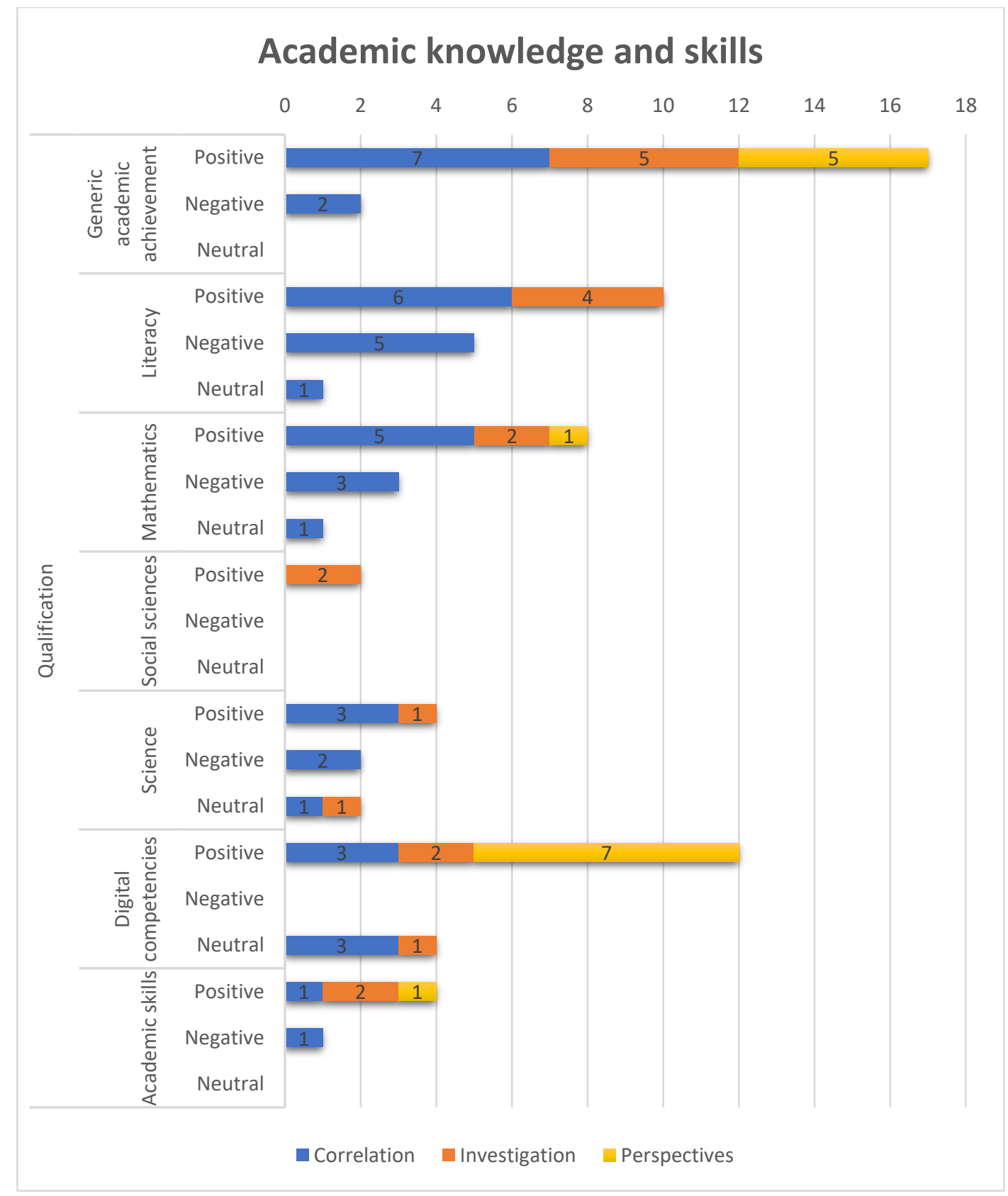

Figure 5. Qualifications: Academic knowledge and skills

Generic academic achievement

Studies which reported students' overall achievement when examining outcomes and home Internet use were categorized as generic academic achievement. A positive relationship between home Internet use and generic academic achievement was reported in 17 studies and a negative relationship in two. In five reviewed studies, students and parents reported that home Internet access has a positive impact on academic performance at school (Alshehri, 2017; Oyaid, 2010; Şad, Özer, \& Acar, 2016; Selwyn, Potter, \& Cranmer, 2009; Smith, 2008). While perspectives data may have an element of bias due to the investment made, the correlation and intervention studies suggest that home Internet does have a relationship to general academic achievement. 
A positive correlation was identified between academic achievement and children from high socio-economic families with home Internet access (Agić, Osmanbegović, \& Suljić, 2016; Gunduz, 2010; Rolleston \& Krutikova, 2014). However, children from high socio-economic household tend to have higher academic achievement regardless of Internet access (Sirin, 2005). Studies also reported improved general academic achievement when students from low-income communities were provided with home Internet access (Araque, 2013; Jewitt \& Parashar, 2011; Kingston, 2013; Wong, Ho, Chen, Gu, \& Zeng, 2015; Yelland \& Neal, 2013). Furlong and Davies (2012) found that Internet access at home can support learning within different contexts.

How children use the Internet at home can influence general academic achievement. A positive correlation occurred when children used the Internet for learning (Kim, Kim, Park, Kim, \& Choi, 2017) and general use of the Internet was related negatively to school academic performance. Another study reported that students who play less computer games achieved better at school compared to those who play more games at home or in Internet café (Pepe, 2011). A further study identified a strong positive correlation between students' Internet self-efficacy and Internet exploring behaviors and their academic performance ( $\mathrm{Li} \&$ Ranieri, 2013). These findings suggest that the educational value of home Internet on generic academic achievement is influenced by how it is used and is correlated to the socio-economic context of the household.

\section{Literacy}

Using the Internet at home is associated positively student achievement in literacy in ten studies and negatively in five studies. A positive correlation was identified between home computer and Internet use and achievement at school in reading (Casey, Layte, Lyons, \& Silles, 2012; Johnson, 2013; Leu et al., 2015), writing (Jesson et al., 2015; Johnson, 2013) and digital media literacy which includes consuming, interacting, critiquing and creating online (Chen, Lin, Lic, \& Lee, 2018; Di Blas \& Paolini, 2013; Leu et al., 2015). However, having the Internet at home does not always correlate to higher literacy scores and the age of participants can influence results. Home Internet access correlated negatively with $5^{\text {th }}$ grade students outcomes while correlated positively with $9^{\text {th }}$ grade students (Wainer, Vieira, \& Melguizo, 2015). A negative correlation was identified in the Turkish 2009 PISA results between home Internet access and reading skills (Acar, 2015) and no significant correlation was found in another study in the same context (Erdogdu \& Erdogdu, 2015).

How the Internet is used at home appears to influence whether it is beneficial for children's literacy. Project based learning online, Internet browsing and emailing were associated with improved reading while downloading music and doing homework on the computer was correlated to lower reading achievement (Casey et al., 2012). Instant messaging was correlated to low literacy skills (Johnson, 2013). Online gaming at the weekend and not during the week correlates to higher literacy achievement (Hartanto, Toh, \& Yang, 2018) as does spending more time online (Chen et al., 2018). Gaming, especially during the week correlate to lower reading skills (Acar, 2015; Hartanto, Toh, \& Yang, 2018). A gender difference was identified, girls spend more time on activities 
such as blogging and participating in online forums than boys which correlated to higher reading achievement (Cheung, Mak, \& Sit, 2013). Literacy specific interventions in the home have enhanced literacy skills (Jesson et al., 2015, McElvain, 2015). The type of online activities at home correlates to literacy outcomes.

\section{Mathematics}

Mathematics achievement was the focus in nine of the reviewed articles. Within these, a positive relationship between home Internet access and mathematics achievement was perceived to exist by teachers (Nicholas \& Fletcher, 2017) and identified in correlation studies (Erdogdu \& Erdogdu, 2015; Reynolds, 2013). A positive relationship was associated with high socio-economic households (Wainer et al., 2015) and in case the students used Internet for studying, surfing, and emailing or they spent less time playing games (Casey et al., 2012; Hartanto et al., 2018). One study identified that unsupervised computer use at home had a positive effect on mathematics learning for nine-year-olds (Casey et al., 2012). However, the correlation between home Internet access and mathematics achievement was found to be weak (Acar Güvendir, 2017) and negative if the children were younger and from low socio-economic households (Wainer et al., 2015).

Similar to literacy, specific learning activities in the home using the Internet can improve mathematics achievement. Students' mathematics achievement at school increased significantly through parents and young children reading together online about mathematical problems (Berkowitz et al., 2015), or playing online mathematics games (Jewitt \& Parashar, 2011). This suggests that the educational value of home Internet use on mathematics can increase through well-designed software.

\section{Social sciences}

Two studies noted a positive effect of home Internet access for social sciences achievement. An online social studies test taken at home improved achievement at school (Park \& Choi, 2008) and historical analytical skills were developed through the use of a wiki at home (Cabiness, Donovan, \& Green, 2013). These were both intervention studies which provides insight into particular types of learning activities. There were no correlation studies in the social sciences which may reflect a lack of national testing data available for analysis. This suggests that home learning activities which develop social science skills or knowledge can improve academic achievement in the social sciences.

\section{Science}

The impact of home Internet access on science achievement has mixed results in the reviewed literature. Two studies reported a positive relationship between having home Internet access and science learning (Liu \& Whitford, 2011; Wang, Liu, \& Zhao, 2012). One study found that some socioeconomic variables including home Internet access had a negative relationship with science achievement (Akyol, Sungur, \& Tekkaya, 2010).Two 
studies found no correlation between home Internet access and science achievement; one analyzed PISA data (Erdogdu \& Erdogdu, 2015) and the other compared homework grades between students undertaking online and paper based homework tasks (Dodson, 2014). Academic performance in science correlated positively when time spent on playing computer games was in the weekends and negatively when playing the games was during the week (Hartanto et al., 2018). This suggests that generic home Internet access has little influence on science achievement.

\section{Digital competencies}

Home Internet access has been identified as a significant predictor of adolescents' Internet savviness (Geyer, 2009). It had a positive correlation with student digital competence (Duarte, Cazelli, Migliora, \& Coimbra, 2013) including those from low-income families (Wong et al., 2015). However, not all studies identified a positive correlation. No relationship was found between home Internet access and digital competencies (Beuermann et al., 2013; Li \& Ranieri, 2010; van Deursen \& Van Diepen, 2013) including students with learning disabilities (Wu, Chen, Yeh, Wang, \& Chang, 2014). The different results could be partially explained by what was measured as digital competencies. The studies with a positive correlation were examining either through perception or testing whether students knew how to do certain tasks on the computer. The studies that identified no significant correlation had a broader definition of digital competencies, including strategic and ethical use. This suggests that the digital competence developed incidentally through Internet use at home may be limited to the technical use of the tools.

While studies that measured digital competence and home Internet access identified a positive or neutral relationship, the perception of students and parents was overwhelmingly positive, which may reflect different interpretations of digital competence. Students perceived that having home Internet access has a positive impact on their digital competence (Kolikant, 2009; Oyaid, 2010; Zilka, 2016) and provide a valuable resource for learning and finding information (Lu, Hao, \& Jing, 2016; Yapici, 2012). Parents' perceptions were similar to students (Khasawneh \& Al-Awidi, 2008; Şad et al., 2016). However, digitally competent students also had behavioral merits like being organised, critical, and thinking strategically that shaped how they use the Internet (Jara, Claro, Ibieta, \& Labbé, 2015). A positive influence correlated to households with supportive, non-controlling parents (Lim, 2009). The development of digital competence through Internet access at home is reported differently depending on what or how data is collected.

\section{Academic skills}

Being organized, critical and thinking strategically are not just digital skills but can be considered to have educational value as generic academic skills. Students who have home Internet access have been found to have developed higher order thinking skills such as critical thinking (Cabiness et al., 2013) problem solving (Lei \& Zhou, 2012) and are able 
to evaluate the quality of the information they acquired from the Internet (Furlong \& Davies, 2012). Students considered that they were more independent learners and have better study habits than other generations who didn't have computers and Internet (Kolikant, 2009). However, the results from studies are not unanimous. In one study students application of cognitive and metacognitive strategies in learning science were found to have a negative correlation to children with home Internet access (Akyol et al., 2010).

\section{Summary. Academic knowledge and skills}

The academic value of home Internet access is reported in general terms and in specific subjects or skills such as literacy, mathematics, science, social sciences, digital competencies and academic skills. These categories reflect the availability of standardized assessment tools used in evaluations like PISA (e.g., Acar, 2015; Liu \& Whitford, 2011) and national assessment data (e.g., Reynolds, 2013; Wainer et al., 2015). The subjects without widespread standardized testing such as the social sciences were the focus of intervention studies rather than correlations. Further intervention studies across categories are needed to identify the nuances of the types of activities with high academic value.

There are more studies related to this function of education than subjectification and socialization. While measuring subjectification and socialization domains depend on specific instruments designed for specific research projects (e.g., Johnson, 2009, 2010).

\section{Subjectification: Strengthening individuality}

Educational value includes strengthening the individual and their autonomy. In the analysis of the reviewed literature the following categories were identified; cognitive development, motivation, self-efficacy, student agency, autonomy and emotional development (Figure 6). 


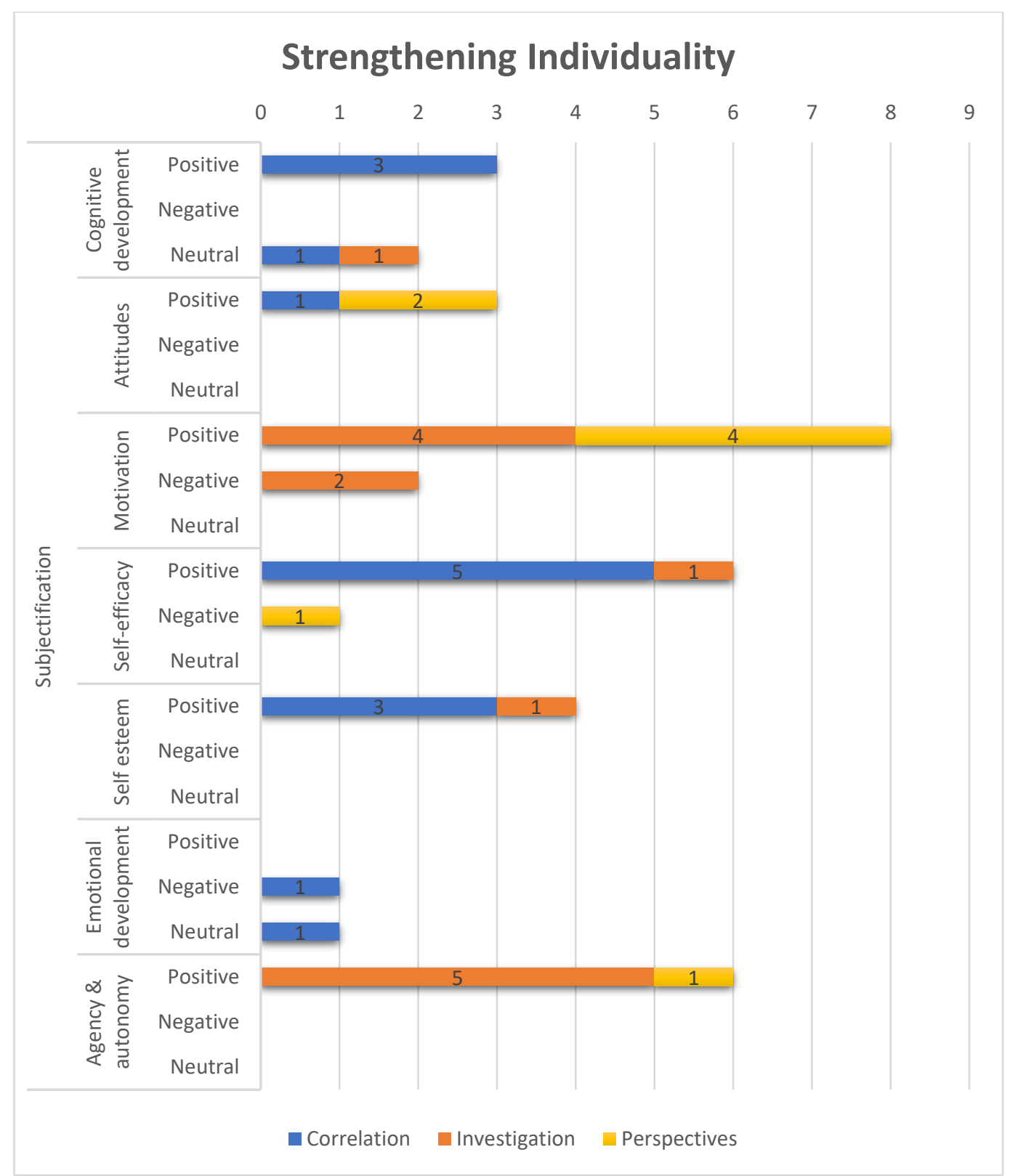

Figure 6. Subjectification: Strengthening individuality

\section{Cognitive development}

Three articles reported a positive relationship or impact of home Internet access on children's psychological and cognitive development. Three linked studies found a positive relationship between using the Internet at home and cognitive development during middle childhood (Johnson, 2009, 2010, 2011). One of these studies concluded that home Internet use accounted for variance in children's cognitive development more than socioeconomic factors (Johnson, 2010). Another identified that the use of the Internet at home for learning and communication, not playing and browsing, were associated with higher cognitive scores (Johnson, 2009). However, not all research articles identified a positive effect on cognitive development, a study that explored one laptop per child scheme in Peru found no significant increase in cognitive development 
for participants (Beuermann et al., 2013). Like academic achievement, how the Internet is used appears to influence its value with regards to cognitive development.

\section{Attitudes and motivation}

Motivation and attitude are important individual characteristics that contribute to engagement with learning. Children who are new to home Internet access have been found to develop positive attitudes towards technology (Lei \& Zhou, 2012; Lu, Li, et al., 2016; Oyaid, 2010), be more motivated (McElvain, 2015), engage with homework activities (Alshehri, 2017; Di Blas \& Paolini, 2013; Jewitt \& Parashar, 2011; Smith, 2008; Starkey et al., 2017) and increase their efforts at school (Kolikant, 2009; Yapici, 2012). However, this is not always the case. Students may exert less effort at school (Beuermann et al., 2013) and where two classes were given the same homework task with one online and the other in the usual paper based format, lower participation levels were identified for the online tasks (Dodson, 2014) which suggests that replacing traditionally formatted activities with the same in digital format is not necessarily motivational. Motivation and attitude towards learning or school will not necessarily improve when children have home Internet access.

\section{Self-esteem and self-efficacy}

Home Internet access has been correlated to or influenced student positive self-esteem (Johnson, 2011; Lei \& Zhou, 2012; Wong et al., 2015) and self-efficacy (Lei \& Zhou, 2012; Li \& Ranieri, 2013; Liao, Chang, Wang, \& Sun, 2016; Wong et al., 2015; Zhao, Lu, Huang, \& Wang, 2010). Parents reported that Mexican immigrant children provided with Internet access as a part of bridging project felt more confident and responsible (McElvain, 2015). No studies reported a negative effect on self-esteem or self-efficacy.

\section{Student agency and autonomy}

Student agency and autonomy was a positive outcome for children with home Internet access (Davies, 2011; Furlong \& Davies, 2012; Zilka, 2016) specifically when children were from low socioeconomic households (Jewitt \& Parashar, 2011; Starkey et al., 2017; Wilkin, 2017). Examples of agency and autonomy in the reviewed literature include students researching topics through self-directed independent learning (Jewitt \& Parashar, 2011) and managing time (Furlong \& Davies, 2012) which are examples of contemporary curriculum goals likely to be included in homework activities.

\section{Emotional development}

Two studies explored emotional development. One found no correlation between home Internet use and emotional development (Johnson, 2010). The other found that home Internet access had a positive relationship with children' habituation to computer use which in turn was found to delay the socio-emotional development (Seo, Chun, Jwa, \& Choi, 2011). The latter study concluded that using Internet at home may have greater 
impact on children' emotional development compared to using Internet at school where it is usually supervised and restricted. Further studies with mixed methods are needed to investigate the impact on young children emotional development. These findings suggest that how and when children use the Internet at home can influence their emotional development.

\section{Summary of subjectification in the research.}

Like the research into qualifications educational value, how students use the Internet appears to influence subjectification outcomes. However, when the Internet was introduced to young people there was a 'moral panic' in the media about the effects it might have (Facer, 2012). Earlier research in this review was dominated by perspectives or correlation methods, which reflects the focus on identifying whether children's use of the Internet at home is a good or a bad thing and for whom. The Internet enables access to a range of resources, activities, information and people at a time that personalization of education is becoming an expectation where students develop autonomous behaviors as active learners (Starkey, 2019). More recent research reviewed included investigations which explore the nuances of how the use of the Internet at home can or cannot develop aspects of individuality reflecting a change from what or who questions to how.

\section{Socialization: Future citizens}

Socialization is the third function of education and involves preparing students to participate in society in the future (Figure 7). Unlike a common belief that children's Internet use at home has a negative impact on the social life of the young generation, all but one of the reviewed studies indicated that having home Internet access is associated positively with children's social skills.

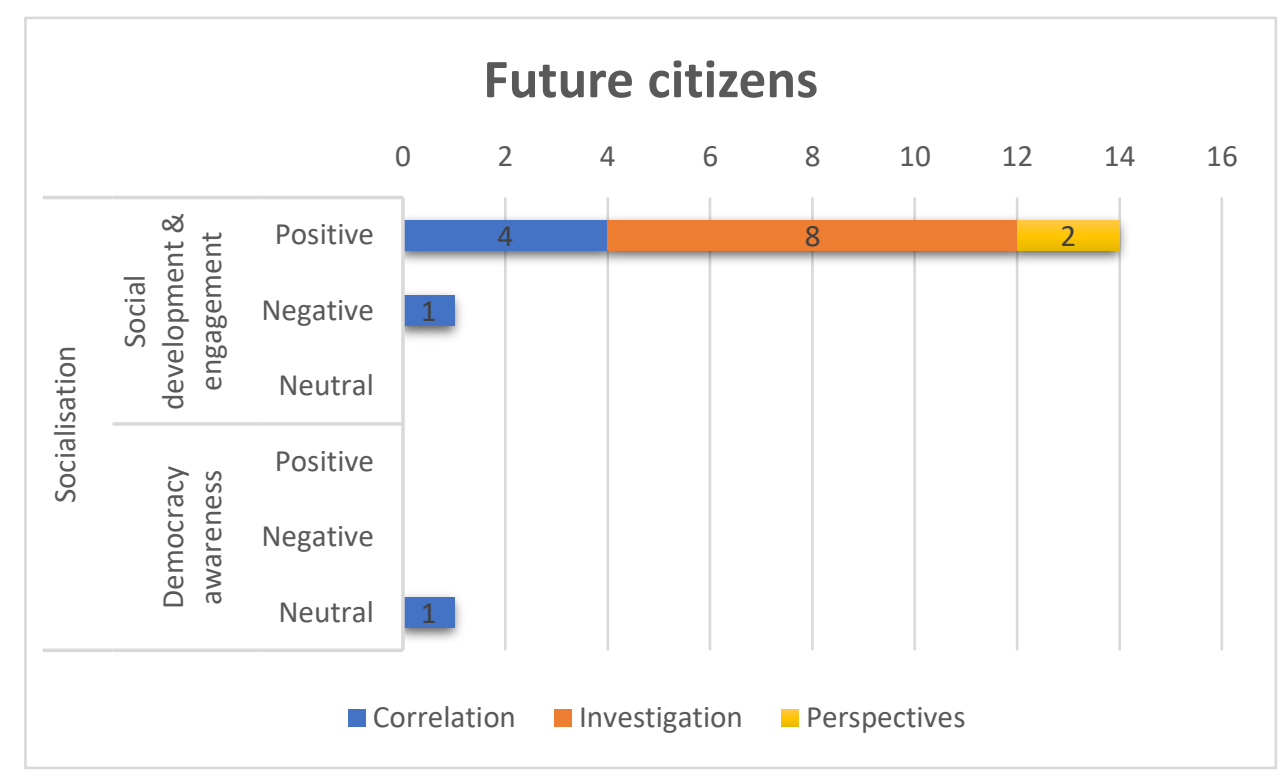

Figure 7. Socialisation: Future citizens 
Using the Internet at home had a positive correlation with social development (Johnson, 2010) and family and peer relationships for children from low-income families (Wong et al., 2015). Using the Internet at home enabled children to collaborate online which develops social and collaboration skills (Anastasiades, Vitalaki, \& Gertzakis, 2008; Cabiness et al., 2013; Di Blas \& Paolini, 2013; Furlong \& Davies, 2012). Children's social skills improved when participating in a programme that targeted immigrant families (McElvain, 2015), low-socioeconomic communities (Yelland \& Neal, 2013) or used certain online applications (Kooiman \& Sheehan, 2015). Children felt that the Internet helped them to integrate into the social fabric (Wilkin, 2017; Zilka, 2016), including feeling more confident about their active participation in everyday education, social and community activities (Yelland \& Neal, 2013). Using social networks children were able to seek help when doing homework (Jewitt \& Parashar, 2011). However, children's habitual computer overuse had an indirect negative impact on social development (Seo et al., 2011).

An important aspect of participating in society is included in citizenship education. However, having the Internet at home had no correlation to democratic awareness in Turkish students (Yildiz \& SeferoĞLu, 2014). This suggests that just because students have access to the Internet does not mean that they will use it in ways that have a range of positive educational outcomes.

\section{Summary of socialization in the research.}

The literature reviewed suggests that home Internet access has a positive influence or correlation with socialization. While online social interaction can lead to concern about inappropriate behavior between young people (Livingstone, Haddon, Görzig, \& Ólafsson, 2011), this was not identified as an aspect of negative educational value in the reviewed literature. Likewise, citizenship education was only identified in one reviewed article.

\section{Conclusion}

This review aimed to evaluate the educational value of home Internet access. Across the papers reviewed, a range of outcomes or correlations were identified between children's access to the Internet at home and educational value. Of these, $86 \%$ identified a positive relationship where access improved educational achievement or skills, $14 \%$ were negative and $10 \%$ were neutral. Therefore, we conclude that access to the Internet at home can have educational value, however, it is not a straightforward correlation or causation. The value is influenced by variables such as socio-economic status and how the technology is used which require further research to develop further understanding.

Educational value was identified across the three functions of education: qualification, subjectification and socialization (Biesta, 2009). The dominant area examined in the literature was within the qualification function. While most of the studies identified a positive correlation, the educational value within academic achievement appeared to be influenced by the alignment between the types of online activities and what was being measured. Where the online activity related to academic learning there was likely to be more benefit than generic online use. The studies which identified a 
correlation between Internet use at home and academic achievement are confounded by socio-economic variables.

The Internet enhances socialization opportunities for young people through learning platforms, social media, applications, games or communication tools such as instant messaging. In the majority of studies and the intervention studies in particular, the second function of education, socialization, was found to be enhanced through Internet. Having the Internet at home was positively related to motivation, agency, autonomy, and self-efficacy, aspects of the third function of education, individualization. However, when the use was habitual it was negatively related to emotional and social development (Seo et al., 2011).

Overall, online activities that explicitly or implicitly align with curriculum goals have greater educational value than generic use. In the digital age a curriculum is likely to emphasize socialization aspects in a digital context and the development of the young person as an individual, including aspects such as agency and autonomy which can be attributed to navigating information available through the Internet (Starkey, 2016). Educational value is greater when the curriculum and Internet use at home align with the functions of education within the context of the digital age.

Furlong and Davies (2012) concluded that 'ICTs become such powerful learning tools for young people when they enter the home' (p.60), however, this review suggests that while the Internet at home does have educational value, this is not always the case. In an equitable society all children should have access to the Internet at home to avoid disadvantaging groups, particularly those in low income households. To maximize the educational value of this access, online activities should align with curriculum goals and the three functions of education.

\section{Limitations}

This study was an exploratory, bounded review which synthesized research through a descriptive method to examine the educational value of home Internet access. The decision of using this method was to cover the diverse methodologies and foci of the research and the variation between studies did not allow for effect sizes to be meaningfully calculated.

Use of findings in this literature review requires caution. Most of the studies reported correlations which means they indicate the existence of the relationship between variables but cannot indicate that one variable results the other (Creswell, 2012). Home Internet access was sometimes integrated with other factors such as examining the socioeconomic status of the students, which means there were intertwined factors affecting educational outcomes. In addition, the data gathered in correlational and perspectivesfocused studies were mainly from self-report questionnaires or interviews which are inherently subjective, especially when participants may have invested in technology and access in the belief that there is educational value. Investigation-focused studies that draw from multiple data sources provide more robust evidence than correlational and perspectives-focused studies, (Gonyea, 2005) however, the three reports within this category were not peer reviewed. Another reason for considering the findings cautiously 
is the time lag in literature reporting the outcomes of initiatives or interventions to provide home Internet access to school aged students. Findings can be outdated because of the rapid development and use of technology for learning at home (Honey, Culp, \& Carrigg, 2000).

Funding: This work was supported by the New Zealand Ministry of Education under the SOW 1 - Equitable Digital Access Grant.

\section{References}

Acar Güvendir, M. (2017). Determination of the Relationship between the Students' "Mathematical Literacy" and "Home and School Educational Resources" in Program for International Student Assessment - (PISA 2012). Mersin Üniversitesi Eğitim Fakültesi Dergisi, 13(1), 94-109. doi:10.17860/mersinefd.305762

Acar, T. (2015). Examination of the PISA 2009 reading skills and information and communication technology (ICT) use skills of Turkish students. Educational Research and Reviews, 10(13), 1825-1831.

Agić, H., Osmanbegović, E., \& Suljić, E. (2016). The Impact of Certain SocioDemographic Conditions on the Students' Success in Learning. Research in Pedagogy, 6(2), 8-20. doi:10.17810/2015.31

Akyol, G., Sungur, S., \& Tekkaya, C. (2010). The contribution of cognitive and metacognitive strategy use to students' science achievement. Educational Research and Evaluation, 16(1), 1-21. doi:10.1080/13803611003672348

Alshehri, A. A. (2017). The Perception Created of Online Home Work by High School Student, Their Teacher and Parents in Saudi Arabia. Journal of Education and Practice, 8(13), 85-100.

Anastasiades, P. S., Vitalaki, E., \& Gertzakis, N. (2008). Collaborative learning activities at a distance via interactive videoconferencing in elementary schools: Parents' attitudes. Computers \& Education, 50(4), 1527-1539. doi:10.1016/j.compedu.2007.02.003

Araque, J., Bravo, N., Estrada, I., Evans, R., Hubchik, K., Kirby, K., \& Reddy, M. (2013). Computer usage and access in low-income urban communities. Computers in Human Behavior, 29(4), 1393-1401. doi:10.1016/j.chb.2013.01.032

Berkowitz, T., Schaeffer, M. W., Maloney, E. A., Peterson, L., Gregor, C., Levine, S. C., $\&$ Beilock, S. L. (2015). Math at home adds up to achievement in school. Science, 350(6257), 196-198. doi:10.1126/science.aac7427

Beuermann, D. W., Cristia, J. P., Cruz-Aguayo, Y., Cueto, S., \& Malamud, O. (2013). Home computers and child outcomes: Short-term impacts from a randomized experiment in Peru. NBER Working Paper No. 18818. doi:10.3386/w18818.

Biesta, G. (2009). Good education in an age of measurement: on the need to reconnect with the question of purpose in education. Educational Assessment, Evaluation and Accountability(formerly: Journal of Personnel Evaluation in Education), 21(1), 33-46. doi:10.1007/s11092-008-9064-9 
Brisson-Boivin, K. (2018). The Digital Well-Being of Canadian Families. MediaSmarts. Ottawa. Retrieved from https://mediasmarts.ca/sites/default/files/publicationreport/full/digital-canadian-families.pdf

Buckingham, D., Banaji, S., Carr, D., Cranmer, S., \& Willett, R. (2005). The media literacy of children and young people: a review of the research literature. In: Ofcom.Retrieved from: https://discovery.ucl.ac.uk/id/eprint/10000145/1/Buckinghammedialiteracy.pdf

Cabiness, C., Donovan, L., \& Green, T. D. (2013). Integrating Wikis in the Support and Practice of Historical Analysis Skills. TechTrends, 57(6), 38-48. Retrieved from doi:10.1007/s11528-013-0700-y

Casey, A., Layte, R., Lyons, S., \& Silles, M. (2012). Home computer use and academic performance of nine-year-olds. Oxford Review of Education, 38(5), 617-634. doi:10.1080/03054985.2012.731207

Chen, D.T., Lin, T.B., Lic, J.Y., \& Lee, L. (2018). Establishing the norm of new media literacy of Singaporean students: Implications to policy and pedagogy. Computers \& Education, 124. doi:10.1016/j.compedu.2018.04.010

Cheung, K.C., Mak, S.K., \& Sit, P.S. (2013). Online Reading Activities and ICT Use as Mediating Variables in Explaining the Gender Difference in Digital Reading Literacy: Comparing Hong Kong and Korea. The Asia-Pacific Education Researcher, 22(4), 709-720. doi:10.1007/s40299-013-0077-x

Davies, C. (2011). Digitally Strategic: How Young People Respond to Parental Views about the Use of Technology for Learning in the Home. Journal of Computer Assisted Learning, 27(4), 324-335. doi:10.1111/j.1365-2729.2011.00427.x

Di Blas, N., \& Paolini, P. (2013). Beyond the School's Boundaries: PoliCultura, a LargeScale Digital Storytelling Initiative. Educational Technology \& Society, 16(1), 15-27.

Dodson, R. J. (2014). The Impact of Online Homework on Class Productivity. Science Education International, 25(4), 354-371.

Duarte, R., Cazelli, S., Migliora, R., \& Coimbra, C. (2013). Computer Skills and Digital Media Uses among Young Students in Rio de Janeiro. Education Policy Analysis Archives, 21(53), 33.

Epstein, J. L., \& Van Voorhis, F. L. (2001). More than minutes: Teachers' roles in designing homework. Educational Psychologist, 36(3), 181-193. doi:10.1207/S15326985EP3603_4

Erdogdu, F., \& Erdogdu, E. (2015). The impact of access to ICT, student background and school/home environment on academic success of students in Turkey: An international comparative analysis. Computers \& Education, 82, 26-49. doi:10.1016/j.compedu.2014.10.023

Facer, K. (2012). After the moral panic? Reframing the debate about child safety online. Discourse: Studies in the cultural politics of education, 33(3), 397-413. doi:10.1080/01596306.2012.681899

Ferguson, R., Faulkner, D., Whitelock, D., \& Sheehy, K. (2015). Pre-teens' informal learning with ICT and Web 2.0. Technology, Pedagogy and Education, 24(2), 247-265. doi:10.1080/1475939X.2013.870596 
Furlong, J., \& Davies, C. (2012). Young People, New Technologies and Learning at Home: Taking Context Seriously. Oxford Review of Education, 38(1), 45-62. doi:10.1080/03054985.2011.577944

Geyer, R. W. (2009). Developing the Internet-Savviness (IS) Scale: Investigating the Relationships between Internet Use and Academically Talented Middle School Youth. RMLE Online, 32(5), 1-20. doi:10.1080/19404476.2009.11462058

Gonyea, R. M. (2005). Self-reported data in institutional research: Review and recommendations. New Directions for Institutional Research, 2005(127), 73-89. doi:10.1002/ir.156

Gunduz, H. B. (2010). Digital Divide in Turkish Primary Schools: Sakarya Sample. Turkish Online Journal of Educational Technology, 9(1), 43-53.

Hallinger, P. (2013). A conceptual framework for systematic reviews of research in educational leadership and management. Journal of Educational Administration, 51(2), 126-149. doi:10.1108/09578231311304670

Hartanto, A., Toh, W. X., \& Yang, H. (2018). Context counts: The different implications of weekday and weekend video gaming for academic performance in mathematics, reading, and science. Computers \& Education, 120, 51-63. doi:10.1016/j.compedu.2017.12.007

Honey, M., Culp, K. M., \& Carrigg, F. (2000). Perspectives on Technology and Education Research: Lessons from the Past and Present. Journal of Educational Computing Research, 23(1), 5-14. doi:10.2190/7VV9-4G08-U0BX-REEJ

Jara, I., Claro, M. H., Juan, E., San Martín, E., Rodríguez, P., Cabello, T., Ibieta, A., \& Labbé, C. (2015). Understanding factors related to Chilean students' digital skills: A mixed methods analysis. Computers \& Education, 88, 387-398. doi:10.1016/j.compedu.2015.07.016

Jesson, R., Meredith, M., \& Rosedale, N. (2015). Porous learning: what do families and schools need. Retrieved from http://www.tlri.org.nz/sites/default/files/projects/TLRI_Jesson_Summary(v2).pd $\underline{f}$

Jewitt, C., \& Parashar, U. (2011). Technology and learning at home: findings from the evaluation of the Home Access Programme pilot. Journal of Computer Assisted Learning, 27(4), 303-313. doi:10.1111/j.1365-2729.2011.00434.x

Johnson, G. (2009). At-Home Online Behavior and Cognitive Development during Middle Childhood. Technology, Instruction, Cognition \& Learning, 6(3), 213229.

Johnson, G. (2010). Internet Use and Child Development: The Techno-Microsystem. Australian Journal of Educational \& Developmental Psychology. 10. (32-43).

Johnson, G. (2011). Internet Activities and Developmental Predictors: Gender Differences among Digital Natives. Journal of Interactive Online Learning, 10(2), 64-76.

Johnson, G. (2013). Traditional Literacy Skills and Internet Use Among 8- to 12-YearOld Children. Reading Psychology, 34(5), 486-506. doi:10.1080/02702711.2012.658144 
Kerawalla, L., O'Connor, J., Underwood, J., duBoulay, B., Holmberg, J., Luckin, R., . . Tunley, H. (2007). Exploring the potential of the homework system and tablet PCs to support continuity of numeracy practices between home and primary school. Educational Media International, 44(4), 289-303. doi:10.1080/09523980701680904

Khasawneh, O. M., \& Al-Awidi, H. M. (2008). The Effect of Home Computer Use on Jordanian Children: A Parental Perspective. Journal of Educational Computing Research, 39(3), 267-284. doi:10.2190/EC.39.3.d

Kim, S. Y., Kim, M., Park, B., Kim, J., \& Choi, H. G. (2017). The associations between internet use time and school performance among Korean adolescents differ according to the purpose of internet use. PloS one, 12(4), e0174878.

Kingston, K. J. (2013). The impact of high-speed Internet connectivity at home on eighthgrade student achievement. (Doctor of Education), University of Nebraska, Omaha.

Kiriakidis, P. S., \& Kavoura, P. A. (2010). Cyberbullying: A Review of the Literature on Harassment Through the Internet and Other Electronic Means. Family \& Community Health, 33(2), 82-93. doi:10.1097/FCH.0b013e3181d593e4

Kitchenham, B. (2004). Procedures for performing systematic reviews. Keele, UK, Keele University, 33(2004), 1-26.

Kolikant, Y. B.-D. (2009). Students' Perceptions of the Appropriateness and Usefulness of the Internet for School Work and the Value of School. Journal of Educational Computing Research, 41(4), 407-429. doi:10.2190/EC.41.4.b

Kooiman, B. J., \& Sheehan, D. P. (2015). The efficacy of exergames for social relatedness in online physical education. Cogent Education, 2(1), 1-1. doi:10.1080/2331186X.2015.1045808

Lei, J., \& Zhou, J. (2012). Digital Divide: How Do Home Internet Access and Parental Support Affect Student Outcomes? Education Sciences, 2(1), 45-53. doi:10.3390/educ2010045

Lei, J., Zhou, J., \& Wang, Q. (2009). Internet Use Among Middle School Students in School and at Home: What Can We Learn From a U.S.-China Comparison? Computers in the Schools, 26(2), 147-164. doi:10.1080/07380560902906104

Leu, D., Forzani, E., Rhoads, C., Maykel, C., Kennedy, C., \& Timbrell, N. (2015). The New Literacies of Online Research and Comprehension: Rethinking the Reading Achievement Gap. Reading Research Quarterly, 50(1), 37-59. doi:10.1002/rrq.85

Li, Y., \& Ranieri, M. (2010). Are 'digital natives' really digitally competent?-A study on Chinese teenagers. Part of a special issue: Learning objects in progress, 41(6), 1029-1042. doi:10.1111/j.1467-8535.2009.01053.x

Li, Y., \& Ranieri, M. (2013). Educational and social correlates of the digital divide for rural and urban children: A study on primary school students in a provincial city of China. Computers \& Education, 60(1), 197-209. doi:10.1016/j.compedu.2012.08.001

Liao, P.-A., Chang, H.-H., Wang, J.-H., \& Sun, L.-C. (2016). What are the determinants of rural-urban digital inequality among schoolchildren in Taiwan? Insights from 
Blinder-Oaxaca decomposition. Computers \& Education, 95, 123-133. doi:10.1016/j.compedu.2016.01.002

Lim, S. S. (2009). Home, School, Borrowed, Public or Mobile: Variations in Young Singaporeans' Internet Access and Their Implications. Journal of ComputerMediated Communication, 14(4), 1228-1256. doi:10.1111/j.10836101.2009.01488.x

Lissak, G. (2018). Adverse physiological and psychological effects of screen time on children and adolescents: Literature review and case study. Environmental Research, 164, 149-157. doi:10.1016/j.envres.2018.01.015

Liu, X., \& Whitford, M. (2011). Opportunities-to-learn at home: Profiles of students with and without reaching science proficiency. Journal of Science Education \& Technology, 20(4), 375-387. doi:10.1007/s10956-010-9259-y

Livingstone, S., Haddon, L., Görzig, A., \& Ólafsson, K. (2011). Risks and safety on the internet: the perspective of European children: full findings and policy implications from the EU Kids Online survey of 9-16 year olds and their parents in 25 countries. LSE, London: EU Kids Online. Retrieved from: http://eprints.lse.ac.uk/33731/1/Risks\%20and\%20safety\%20on\%20the\%20inter net(lsero).pdf

Lu, J., Hao, Q., \& Jing, M. (2016). Consuming, sharing, and creating content: How young students use new social media in and outside school. Computers in Human Behavior, 64, 55-64. doi:10.1016/j.chb.2016.06.019

Lu, J., Li, D., Stevens, C., \& Ye, R. (2016). How Do Students Evaluate Computer Use for Learning? Journal of Educational Computing Research, 54(6), 793-815. doi:10.1177/0735633116636771

McElvain, C. M. (2015). The Bridge Project: Connecting Home, School, and Community for Mexican Immigrant Children. Journal of Latinos and Education, 14(3), 153170. doi:10.1080/15348431.2014.973568

Nicholas, K., \& Fletcher, J. (2017). What Is Happening in the Use of ICT Mathematics to Support Young Adolescent Learners? A New Zealand Experience. Educational Review, 69(4), 474-489. doi:10.1080/00131911.2016.1237476

Oyaid, A. A. (2010). Secondary Student's Perceptions of Information and Communication Technology and Their Usage of It Inside and Outside of School in Riyadh City, Saudi Arabia. International Journal of Applied Educational Studies, 7(1), 27-42.

Özgür, H. (2016). The relationship between Internet parenting styles and Internet usage of children and adolescents. Computers in Human Behavior, 60(C), 411-424. doi:10.1016/j.chb.2016.02.081

Park, J., \& Choi, B. C. (2008). Higher retention after a new take-home computerised test. British Journal of Educational Technology, 39(3), 538-547. doi:10.1111/j.14678535.2007.00752.x

Paulus, F. W., Ohmann, S., Von Gontard, A., \& Popow, C. (2018). Internet gaming disorder in children and adolescents: a systematic review. Developmental Medicine \& Child Neurology, 60(7), 645-659. doi.org/10.1111/dmcn.13754 
Pepe, K. (2011). A Study on the Playing of Computer Games, Class Success and Attitudes of Parents to Primary School Students. Educational Research and Reviews, 6(9), 657-663.

Reynolds, A. (2013). Does a student's use of technology outside school affect mathematic achievement in school? (Doctor of Education), St John's University, New York.

Rolleston, C., \& Krutikova, S. (2014). Equalising opportunity? School quality and home disadvantage in Vietnam. Oxford Review of Education, 40(1), 112-131. doi:10.1080/03054985.2013.875261

Şad, S., Sami, A., Özer, N., \& Acar, F. (2016). Parental e-nvolvement: a phenomenological research on electronic parental involvement. International Journal of Pedagogies \& Learning, 11(2), 163-186. doi:10.1080/22040552.2016.1227255

Selwyn, N., Potter, J., \& Cranmer, S. (2009). Primary Pupils' Use of Information and Communication Technologies at School and Home. British Journal of Educational Technology, 40(5), 919-932. doi:10.1111/j.1467-8535.2008.00876.x

Seo, H. A., Chun, H. Y., Jwa, S. H., \& Choi, M. H. (2011). Relationship between young children's habitual computer use and influencing variables on socio-emotional development. Early Child Development and Care, 181(2), 245-265. doi:10.1080/03004430.2011.536644

Sirin, S. R. (2005). Socioeconomic status and academic achievement: A meta-analytic review of research. Review of educational research, 75(3), 417-453.

Smith, J. O. (2008). Parental perceptions of home Internet use among rural African American families. (Doctorate of Curriculum and Instruction), Grambling State University, New Orleans, Louisianna.

SQW. (2011). Evaluation of the home access programme - Final report. Retrieved from https://assets.publishing.service.gov.uk/government/uploads/system/uploads/atta chment_data/file/181525/DFE-RR132.pdf

Starkey, L., Sylvester, A., \& McRae, H. (2017). School initiated learning at home in a digital age 2017 Final Report. Retrieved from https://www.researchgate.net/publication/321807810_School_initiated_learning _at_home_in_a_digital_age_2017_Final_Report

Starkey, L. (2016). An equitable curriculum for a digital age. Curriculum Matters, 12, 29-45. doi:10.18296/cm.0012

Starkey, L. (2019). Three dimensions of student-centred education: a framework for policy and practice. Critical Studies in Education,60(3), 375-390. doi:10.1080/17508487.2017.1281829

Torraco, R. J. (2016). Writing Integrative Literature Reviews: Using the Past and Present to Explore the Future. Human Resource Development Review, 15(4), 404-428. doi:10.1177/1534484316671606

UFBNZ. (2018). Ultra-fast broadband, New Zealand. Retrieved from https://ufb.org.nz van Deursen, A. J. A. M., \& Van Diepen, S. (2013). Information and strategic Internet skills of secondary students: A performance test. Computers \& Education, 63, 218-226. doi:10.1016/j.compedu.2012.12.007 
Wainer, J., Vieira, P., \& Melguizo, T. (2015). The association between having access to computers and Internet and educational achievement for primary students in Brazil. Computers \& Education, 80, 68-76. doi:10.1016/j.compedu.2014.08.007

Wang, S., Liu, X., \& Zhao, Y. (2012). Opportunities to learn in school and at home: How can they predict students' understanding of basic science concepts and principles? International Journal of Science Education, 34(13), 2061-2088. doi:10.1080/09500693.2012.709335

Whitehouse. (2015). ConnectED initiative. Retrieved from https://obamawhitehouse.archives.gov/issues/education/k-12/connected

Wilkin, S. D., Huw, E., \& Jesson, R. (2017). Addressing digital inequalities amongst young people: conflicting discourses and complex outcomes. Oxford Review of Education, 43(3), 332-347. doi:10.1080/03054985.2017.1305058

Wong, Y. C., Ho, K. M., Chen, H., Gu, D., \& Zeng, Q. (2015). Digital divide challenges of children in low-income families: The case of Shanghai. Journal of Technology in Human Services, 33(1), 53-71. doi:10.1080/15228835.2014.998576

Wu, T.-F., Chen, M.-C., Yeh, Y.-M., Wang, H.-P., \& Chang, S. C.-H. (2014). Is digital divide an issue for students with learning disabilities? Computers in Human Behavior, 39, 112-117. doi:10.1016/j.chb.2014.06.024

Yapici, I., Hasan, A. (2012). High school students' views on blended learning. Turkish online journal of distance education, 13(4).

Yelland, N., \& Neal, G. (2013). Aligning digital and social inclusion: A study of disadvantaged students and computer access. Education and Information Technologies, 18(2), 133-149. doi:10.1007/s10639-012-9223-y

Yildiz, H., \& SeferoĞLu, S. S. (2014). Overview of Digital Divide and Democracy Awareness: Primary School Students' Opinions. Education \& Science, 39(171), 86-98.

Zhao, L., Lu, Y., Huang, W., \& Wang, Q. (2010). Internet inequality: The relationship between high school students' Internet use in different locations and their Internet self-efficacy. Computers \& Education, 55(4), 1405-1423. doi:10.1016/j.compedu.2010.05.010

Zilka, G. (2016). Reducing the digital divide among children who received desktop or hybrid computers for the home. Journal of Information Technology Education, 15, 233-251. 